\title{
Duodenal atresia
}

INSERM

\section{Source}

INSERM. (1999). Orphanet: an online rare disease and orphan drug data base. Duodenal atresia. ORPHA:1203

Duodenal atresia is an embryopathy of the cranial intestine that leads to a complete absence of the duodenal lumen. 